\title{
Turnover of Human and Monkey Plasma Kininogens in
}

\section{Rhesus Monkeys}

\author{
Tadataka Yamada, David A. Wing, Jack V. Pierce, and George W. Pettit, \\ Bacteriology, Pathology, and Animal Assessment Divisions, U. S. Army Medical \\ Research Institute of Infectious Diseases, Fort Detrick, Frederick, Maryland \\ 21701, and The Section on Physiological Chemistry, Laboratory of Chemistry, \\ National Heart, Lung, and Blood Institute, National Institutes of \\ Health, Bethesda, Maryland 20014
}

A B S TRACT The normal metabolic turnover of plasma kininogens was studied by measuring the disappearance of intravenously administered radiolabeled human and monkey plasma kininogens from the circulation of healthy adult rhesus monkeys. Curves obtained by plotting log radioactivity against time could be expressed as double exponential equations, with the first term representing diffusion, and the second, catabolism. No significant difference between the turnovers of human and monkey kininogens was observed. The difference between the $t_{1 / 2}$ of high molecular weight kininogen $(25.95 \pm 1.60 \mathrm{~h}$ ) (mean \pm SEM) and that of low molecular weight kininogen $(18.94 \pm 1.93 \mathrm{~h})$ was only marginally significant $(P$ $<0.05)$. In contrast, a highly significant $(P<0.001)$ difference in their mean catabolic rates $\left(1.12 \pm 0.08 \mathrm{~d}^{-1}\right.$ for high molecular weight kininogen vs. $2.07 \pm 0.09 \mathrm{~d}^{-1}$ for low molecular weight kininogen) was observed. These differences between the two kininogens were attributed to differences in their distribution between the intra- and extravascular pools. Studies of kininogen turnover will be useful in elucidating the in vivo func-

This work was presented in part at the VIth International Congress on Thrombosis and Haemostasis, Philadelphia, Pa., 1 July 1977.

In conducting the research described in this report, the investigators adhered to the "Guide for the Care and Use of Laboratory Animals," as promulgated by the Committee on the Revision of the Guide for Laboratory Animal Facilities and Care of the Institute of Laboratory Animal Resources, National Research Council. The facilities are fully accredited by the American Association for Accreditation of Laboratory Animal Care. The views of the authors do not purport to reflect the positions of the Department of the Army or the Department of Defense. Reprint requests should be addressed to Dr. Yamada, Gastroenterology Division (691/ $111 \mathrm{C})$, Wadsworth VA Hospital, Los Angeles, Calif. 90073.

Received for publication 26 August 1977 and in revised form 17 August 1978. tions of the various kininogens in health as well as during clinical illness.

\section{INTRODUCTION}

The kinins are a group of polypeptides known primarily for their potent vasodilatory actions in addition to their ability to cause increased capillary permeability $(1,2)$. They are generated in plasma through enzymatic cleavage of a precursor protein, kininogen, by plasma kallikrein (3). Plasma kallikrein is formed from its precursor, prekallikrein, and this conversion is dependent upon the presence of activated Hageman factor (blood coagulation Factor XII) (4). Because of their profound physiologic actions, the kinins have been implicated in the pathophysiology of a wide variety of clinical disorders which include carcinoid syndrome (5), hereditary angioedema (6), dumping syndrome (7), Gram-negative septicemia (8), and disseminated intravascular coagulation (9). Documentation of the involvement of the kinin system in these various disorders, however, has been limited to the observation of elevated plasma kinin and kallikrein activities, and the depletion of their precursor proteins, kininogen and prekallikrein. Such observations only imply kinin system activation. No data regarding the specific kinetics of kinin system proteins in these disorders are available.

Recent advances in the isolation and purification of plasma kininogens (10) have enabled us to examine the normal turnover of these proteins. By intravenous injection into rhesus monkeys of radiolabeled, purified human and monkey kininogens, and subsequent measurement of their disappearance, we have endeavored to characterize the kinetics of these proteins in plasma. We hope to use this information to study kininogen turnover in various disease states to clarify the role of the kinin system, if any, in their pathogenesis. 


\section{METHODS}

Isolation of kininogens. Kininogens were purified with the affinity chromatographic methods of Pierce and Guimarães (10) as outlined in Fig. 1. 2 liters of either human or monkey blood were drawn into plastic receptacles which contained 1 part $3.8 \%$ sodium citrate, $0.1 \%$ hexadimethrine bromide (Aldrich Chemical Co., Inc., Milwaukee, Wis.), and $0.01 \mathrm{M}$ benzamidine chloride (Calbiochem, San Diego, Calif.), to 9 parts whole blood. The samples were centrifuged at $25^{\circ} \mathrm{C}$ for $10 \mathrm{~min}$ at $2,000 \mathrm{~g}$, and the plasma supernate $(520 \mathrm{ml})$ was chromatographed on a $2.6-\times 40.0-\mathrm{cm}$ column of L-lysine coupled to Sepharose 4B (Pharmacia Fine Chemicals, Div. of Pharmacia Inc., Piscataway, N. J.) which was prepared as described by Deutsch and Mertz (11). The plasminogen-free plasma $(580 \mathrm{ml})$ thus obtained was stirred into 4 liters of a solution that contained $50 \mathrm{~g}$ dry weight of DEAE-cellulose (DE-23, Whatman Chemicals, Division of $\mathrm{W} \& \mathrm{R}$ Balston, Maidstone, Kent, England), $0.1 \%$ hexadimethrine, and $1 \mathrm{mM}$ benzamidine; titrated to $\mathrm{pH} 6.0$ by the addition of $5 \mathrm{~N} \mathrm{HCl}$. The resulting slurry was stirred vigorously for $2 \mathrm{~h}$, allowed to settle for $30 \mathrm{~min}$, decanted onto a coarse-fritted Buchner funnel, and washed with 5 liters of $0.01 \%$ hexadimethrine- $1 \mathrm{mM}$ benzamide solution. The washed adsorbent was suspended with $67 \mathrm{ml}$ of $3.0 \mathrm{M}$ Tris-HCl buffer, pH 6.0, and enough $0.01 \%$ hexadimethrine$1 \mathrm{mM}$ benzamidine to give a final volume of $250 \mathrm{ml}$. After stirring for $1 \mathrm{~h}$, the suspension was filtered in a coarsefritted Buchner funnel and washed with $500 \mathrm{ml}$ of $0.4 \mathrm{M}$ Tris- $\mathrm{HCl}, 0.01 \%$ hexadimethrine, and $1 \mathrm{mM}$ benzamidine buffer, pH 6.0. The eluate, called prep $\mathrm{A}$, was adjusted to pH 7.2 , and applied at $25^{\circ} \mathrm{C}$ to an affinity column (3.1

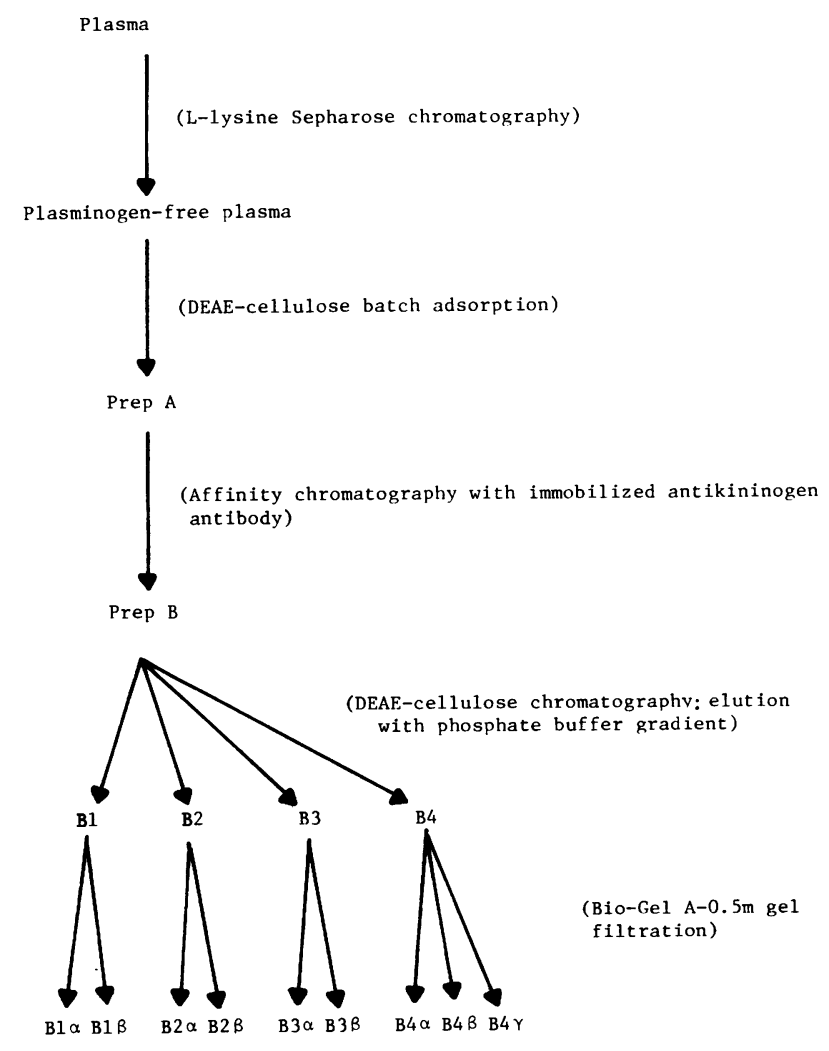

FIGURE 1 Isolation procedure for plasma kininogens. $\times 13.9 \mathrm{~cm}$ ) which was prepared by coupling purified sheep anti-human low molecular weight kininogen to cyanogen bromide-activated Bio-Gel A-50m (Bio-Rad Laboratories, Richmond, Calif.) by the method of March et al. (12). The column was washed with a buffer which contained $0.4 \mathrm{M}$ Tris- $\mathrm{HCl}, 0.01 \%$ hexadimethrine, and $1 \mathrm{mM}$ benzamidine, $\mathrm{pH}$ 6.0, and eluted with $8 \mathrm{M}$ guanidine $\mathrm{HCl}$. The purified kininogen thus obtained, called prep $\mathrm{B}$, was dialyzed against $0.05 \mathrm{M}$ phosphate buffer, $\mathrm{pH} 6.0$, for $24 \mathrm{~h}$ at $25^{\circ} \mathrm{C}$ and chromatographed on a DEAE-cellulose column $(0.9 \times 30.0 \mathrm{~cm})$ at $4^{\circ} \mathrm{C}$. Four main $A_{280}$ peaks coincident with peaks of kininogen activity, called B1, B2, B3, and B4, were eluted with a linear phosphate buffer gradient, $0.05-0.30 \mathrm{M}, \mathrm{pH}$ 6.0. Essentially no difference was observed between human and monkey kininogens in the number or position of the protein peaks. Approximately $48 \%$ of the kininogen activity of the initial plasma was recovered in the total activities of B1-B4. Gel filtration of each of the peaks with Bio-Gel A-0.5m revealed separate kininogen subfractions, called $\alpha, \beta$, and $\gamma$ which corresponded to proteins of molecular weight $80,000,160,000$, and 225,000 , respectively. Whereas $B 1, B 2$, and $B 3$ contained nearly equal amounts of the $\alpha$ and $\beta$ forms, B4 consisted mainly of the $\gamma$ protein $(59 \%)$ with some $\alpha(1 \%)$ and $\beta(40 \%)$ proteins. Hence, for the purposes of our study, we will refer to B4 as high molecular weight $(\mathrm{HMW})^{1}$ kininogen, and a pooled sample consisting of $\mathrm{B} 1, \mathrm{~B} 2$, and B3 as low molecular weight (LMW) kininogen, unless the $\alpha, \beta$, or $\gamma$ speciation is otherwise noted.

Sheep antisera to human LMW kininogens I and II were prepared by the method of Pierce and Webster (13). The antisera were purified by immunoprecipitation followed by chromatography on hydroxyapatite in $8 \mathrm{M}$ urea. ${ }^{2} \mathrm{~A}$ reaction of identity was obtained by Ouchterlony double diffusion with human and monkey HMW and LMW kininogens against the purified monospecific antibody.

Kinin-generating activity of the various kininogen fractions, both before and after radioiodination, was measured by bioassay on guinea pig ileum by the direct method of Prado et al. (14) (modified by Webster and Prado [15] and Pierce and Guimarães [10]). A 3-cm segment of ileum was suspended in $5 \mathrm{ml}$ of Tyrode's solution at $32^{\circ} \mathrm{C}$. An amount of kininogen sample estimated to release $30 \mathrm{ng}$ of lysylbradykinin (kallidin) was added to the bath followed by 10 $\mu l$ of partially purified human urinary kallikrein (10 tosyl L-arginine methyl ester $\mathrm{U} / \mathrm{ml}$ ) prepared by the method of Pierce and Guimarães (10). The magnitude of isotonic contraction of ileum, loaded with $1 \mathrm{~g}$ of tension, caused by the kallidin released from kininogen, was measured with a displacement transducer (Narco Bio-Systems, Inc., Houston, Tex.). Results were quantified with a standard curve of ileal contractions elicited by known quantities of a standard solution of kallidin (Schwarz/Mann Div, Becton, Dickinson \& Co., Orangeburg, N. Y.).

The ability of our HMW kininogen preparation to correct the abnormality in activated partial thromboplastin time observed in HMW kininogen-deficient plasma was examined with a modification of the semiquantitative functional assay initially described by Lacombe et al. (16). A test tube that contained $0.10 \mathrm{ml}$ of $\mathrm{HMW}$ kininogen-deficient plasma (George King Bio-Medical, Inc., Salem, N. H.), $0.05 \mathrm{ml}$ of sample, and $0.10 \mathrm{ml}$ of kaolin $10 \mathrm{mg} / \mathrm{ml}$ Thrombofax

\footnotetext{
${ }^{1}$ Abbreviations used in this paper: ev/iv, extravascular/ intravascular pool ratio(s); Fc, mean catabolic rate(s); Fe, i, return flow; Fi, e, capillary transfer rate; HMW, high molecular weight; LMW, low molecular weight.

${ }^{2}$ Pierce, J. V. Manuscript in preparation.
} 


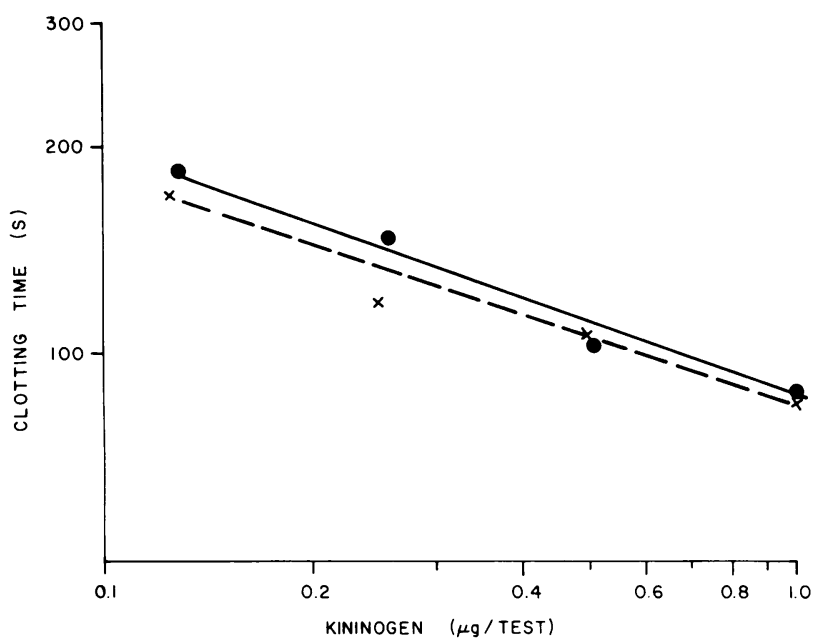

FIGURE 2 Correction of prolonged activated partial thromboplastin time in HMW kininogen-deficient plasma by the addition of HMW kininogen $(x---x)$ and $\left[{ }^{125} \mathrm{I}\right] \mathrm{HMW}$ kininogen $(-\bullet)$.

(Ortho Diagnostics, Inc., Raritan, N. J.) was incubated for 8 min at $37^{\circ} \mathrm{C}$. $0.05 \mathrm{ml}$ of $0.04 \mathrm{M} \mathrm{CaCl}_{2}$ was then added, and clotting time was measured in a fibrometer (Bio Quest, BBL \& Falcon Products, Becton, Dickinson \& Co., Cockeysville, Md.). Results are depicted in Fig. 2.

Iodination of kininogens. Proteins for kinetic studies were radiolabeled with ${ }^{125} \mathrm{I}$ with the microdiffusion method of Gruber and Wright (17). A 50-ml Ehrlenmeyer flask was modified to contain an inner chamber by gluing a 1.3$\times 2.3-\mathrm{cm}$ plastic vial to its bottom. $1 \mathrm{ml}$ of a protein solution at an approximate concentration of $1 \mathrm{mg} / \mathrm{ml}$, calculated from the extinction coefficients of the various kininogens, was placed in the outer chamber of the flask, and $0.2 \mathrm{ml}$ of $0.002 \mathrm{M} \mathrm{KI}$ and $1 \mathrm{mCi}$ of $\mathrm{Na}\left[{ }^{125} \mathrm{I}\right](50 \mathrm{mCi} / \mathrm{ml}$, New England Nuclear, Boston, Mass.) were placed into the inner chamber. The flask was sealed with a rubber skirt-type vaccine stopper and $0.2 \mathrm{ml}$ of a $1: 20$ dilution of a stock acid-dichromate solution $\left(0.27 \mathrm{M} \mathrm{Na} \mathrm{Nr}_{2} \mathrm{O}_{7}\right.$ in $\left.36 \mathrm{~N} \mathrm{H}_{2} \mathrm{SO}_{4}\right)$ was added to the inner chamber with a syringe through a 4-inch 20-gauge needle. The flask was rotated gently at $25^{\circ} \mathrm{C}$ so that no mixing between the two chambers occurred. After $1 \mathrm{~h}$, the radiolabeled protein was removed with a syringe through a 4-inch needle, and separated from unreacted iodine by gel filtration on a $1.5-\times 5.5-\mathrm{cm}$ column of Sephadex G-25 (Pharmacia Fine Chemicals, Div of Pharmacia Inc., Piscataway, N. J.). Efficiency of labeling with this technique was generally low (4.6-9.7\%), but the kininogens retained practically all of their kinin-generating activity (96.7-99.2\%) after iodination. The functional activity of HMW kininogen in correcting the coagulation abnormality of HMW kininogen-deficient plasma was essentially unaltered (Fig. 2).

Animal studies. Adult male rhesus monkeys (Macaca mulatta), which weighed $3.5-6.0 \mathrm{~kg}$, were used. $24 \mathrm{~h}$ before injection of radiolabeled kininogen, each monkey was administered $1 \mathrm{ml}$ of a saturated solution of KI orally; for the duration of the study, all fluid intake was limited to a solution that contained $0.02 \% \mathrm{NaI}$. During the initial injection of kininogen, and for each subsequent blood sampling, the monkeys were anesthetized with ketamine$\mathrm{HCl}(10 \mathrm{mg} / \mathrm{kg}, \mathrm{i} . \mathrm{m}$.). A preparation of iodinated kininogen, in an amount not exceeding $5 \%$ of the total blood content of the kininogen species injected, as estimated from the relative amounts of each specie purified from plasma, was administered to each animal via the saphenous vein. 2 min after injection, a $1.8-\mathrm{ml}$ blood sample was withdrawn from a femoral vein into a siliconized glass, 2-ml Vacutainer tube (Becton, Dickinson \& Co., Rutherford, N. J.) which contained $0.2 \mathrm{ml}$ of $3.8 \%$ sodium citrate, $0.1 \%$ hexadimethrine bromide, and $0.01 \mathrm{M}$ benzamidine, and this was considered the 0 time sample. Subsequent samples were withdrawn at $1-4,6,8,12,16,20,24,28,32,36,40,44$, and $48 \mathrm{~h}$ after injection of radiolabeled kininogen.

From each $2-\mathrm{ml}$ sample, $0.4 \mathrm{ml}$ of whole blood was removed and stored at $-70^{\circ} \mathrm{C}$. The remaining blood was centrifuged at $25^{\circ} \mathrm{C}$ for $10 \mathrm{~min}$ at $2,000 \mathrm{~g}$, and $0.4 \mathrm{ml}$ of plasma supernate was removed and stored at $-70^{\circ} \mathrm{C}$. A second $0.4-\mathrm{ml}$ aliquot of plasma was mixed with $0.4 \mathrm{ml}$ of $0.2 \mathrm{M}$ Tris-acetate, $0.01 \mathrm{M}$ EDTA buffer, $\mathrm{pH} 6.0$, and 0.1 ml of antibody against human LMW kininogen. The mixture was incubated at $4^{\circ} \mathrm{C}$ for $16 \mathrm{~h}$, then centrifuged at $2,000 \mathrm{~g}$ for $10 \mathrm{~min}$ at $4^{\circ} \mathrm{C}$. The resulting supernatant solution, and three subsequent washes of the precipitate with $1 \mathrm{ml}$ of $0.2 \mathrm{M}$ Tris, $0.1 \mathrm{M}$ EDTA buffer, $\mathrm{pH} 6.4$, were poured over a $0.22-\mu \mathrm{m}$ Millipore filter (Millipore Corp., Bedford, Mass.). The filter and the remaining precipitate were placed in a single tube and stored at $-70^{\circ} \mathrm{C}$. At the end of each 48-h study, all the stored preparations were counted in a gamma counter (model 1185, Searle Diagnostics, Inc., subsid. of G. D. Searle \& Co., Des Plaines, Ill.).

The injection schedule of radiolabeled kininogens was as follows: 6 monkeys received human prep B (a mixture of HMW and LMW kininogens), 6 received human HMW kininogen, 4 received human $\mathrm{LMW}$ kininogen, 4 received human $\mathrm{B} 3 \alpha,{ }^{3}$ 4 received human $B 4 \gamma, 4$ received monkey HMW kininogen, and 4 received monkey LMW kininogen.

Data analysis. Turnover of kininogen was assessed with the plasma slope method described in the multiple pipeline model for interstitial albumin distribution by Reeve and Bailey (18). The radioactivity of each sample withdrawn from the monkeys, expressed as a percentage of the radioactivity of the initial (time 0 ) sample for each monkey, was plotted on a logarithmic scale against time after injection of radiolabeled kininogen. In each case, the disappearance curve of injected kininogen from plasma could be expressed as a double exponential equation, $\mathrm{Y}=\mathrm{C}_{1} \mathrm{e}^{-\mathrm{at}}$ $+\mathrm{C}_{2} \mathrm{e}^{-\mathrm{bt}}$, where $\mathrm{Y}$ represents percent of initial counts per minute, $t$ represents time, $C_{1}$ and $C_{2}$ represent the constants of the two exponentials, and $\mathrm{a}$ and $\mathrm{b}$ are the rate constants. The equation that best fits the data for each test was calculated by linear regression analysis using the Simulation Analysis and Modeling (SAAM) program of Berman and Weiss (19) in a Univac 1108 computer (Sperry Univac, Blue Bell, Pa.) at the National Bureau of Standards. Correlation coefficients for the multiple regressions were calculated with the method described by Dixon and Massey (20).

In the double exponential model for fibrinogen turnover, the first, rapid exponential is hypothesized to represent initial diffusion of labeled protein from the intrato the extravascular pool. The second, slower exponential is thought to represent disappearance of fibrinogen from the intravascular pool as a result of catabolism. Assuming a similar hypothesis for kininogen, we used the following

${ }^{3}$ The $A_{280}$ peak B3 actually consisted of two subpeaks, called B3.1 and B3.2. The B3 $\alpha$ used for our studies was B3.2 $\alpha$. 
equations as derived by Regoeczi (21) to calculate mean catabolic rate(s) (Fc), which represents the fraction of intravascular-injected labeled protein catabolized in $24 \mathrm{~h}$; capillary transfer rate $(\mathrm{Fi}, \mathrm{e})$, which represents the fraction of intravascular protein transferred to the extravascular pool in $24 \mathrm{~h}$; return flow $(\mathrm{Fe}, \mathrm{i})$, which represents the fraction of extravascular protein returned to the intravascular pool in $24 \mathrm{~h}$; and extravascular/intravascular pool ratio(s) (ev/iv), which represents the ratio between extraand intravascular pool size:

$$
\begin{aligned}
F c & =\frac{1}{C_{1} / a+C_{2} / b} \times 24 d^{-1}, \\
F i, e & =\left(C_{1} a+C_{2} b\right) \times 24-F c d^{-1}, \\
F e, i & =(a+b) \times 24-(F c+F i, e) d^{-1}, \\
\text { ev/iv } & =\frac{F i, e}{F e, i} .
\end{aligned}
$$

$C_{1}$ and $C_{2}$, as before, represent the constants for the two exponentials and $a$ and $b$ represent the rate constants. Biologic $t_{1 / 2}$ was calculated with the standard equation: $t_{1 / 2}=\ln 2 / b$. The rate constant of the second exponential (b) which expresses the rate of catabolism was used to obtain $t_{1 / 2}$. All statistical comparisons of data were made with Student's $t$ test.

\section{RESULTS}

The disappearance curves of radiolabeled human kininogens from plasma of rhesus monkeys could be expressed as double exponential equations (Fig. 3). Like fibrinogen $(22,23)$, kininogen had a high metabolic rate, and first-order diffusion and catabolic characteristics. HMW and LMW kininogens had similar configurations for their turnover curves, but considerable differences in their kinetics existed. As expected, prep B, a mixture of HMW and LMW kininogens, appeared to share characteristics of both forms of kininogens. A comparison of kinetic parameters between HMW and LMW kininogens is depicted in Table I. Plasma $t_{1 / 2}$ of HMW kininogens was $25.95 \pm 1.60 \mathrm{~h}$ (mean $\pm \mathrm{SEM}$ ), while that of LMW kininogen was $18.94 \pm 1.93 \mathrm{~h}$; a difference that was only marginally significant $(P<0.05)$. On the other hand, a highly significant difference $(P<0.001)$ existed between their Fc. Because plasma $t_{1 / 2}$ is a measure of catabolism of only the kininogen in the intravascular pool, and Fc is dependent upon both intra- and extravascular pools of kininogen, it follows that the observed differences between HMW and LMW kininogens result from differences either in intravascularextravascular flux or in pool size. A significant difference in ev/iv existed, with HMW kininogen being partitioned primarily into the intravascular pool, and LMW kininogen being more equally distributed between the two pools. Although $\mathrm{Fi}$, e of HMW kininogen was slower than that of LMW kininogen, the difference was not significant. No significant difference was found in $\mathrm{Fe}$, $\mathrm{i}$ for the two kininogens.

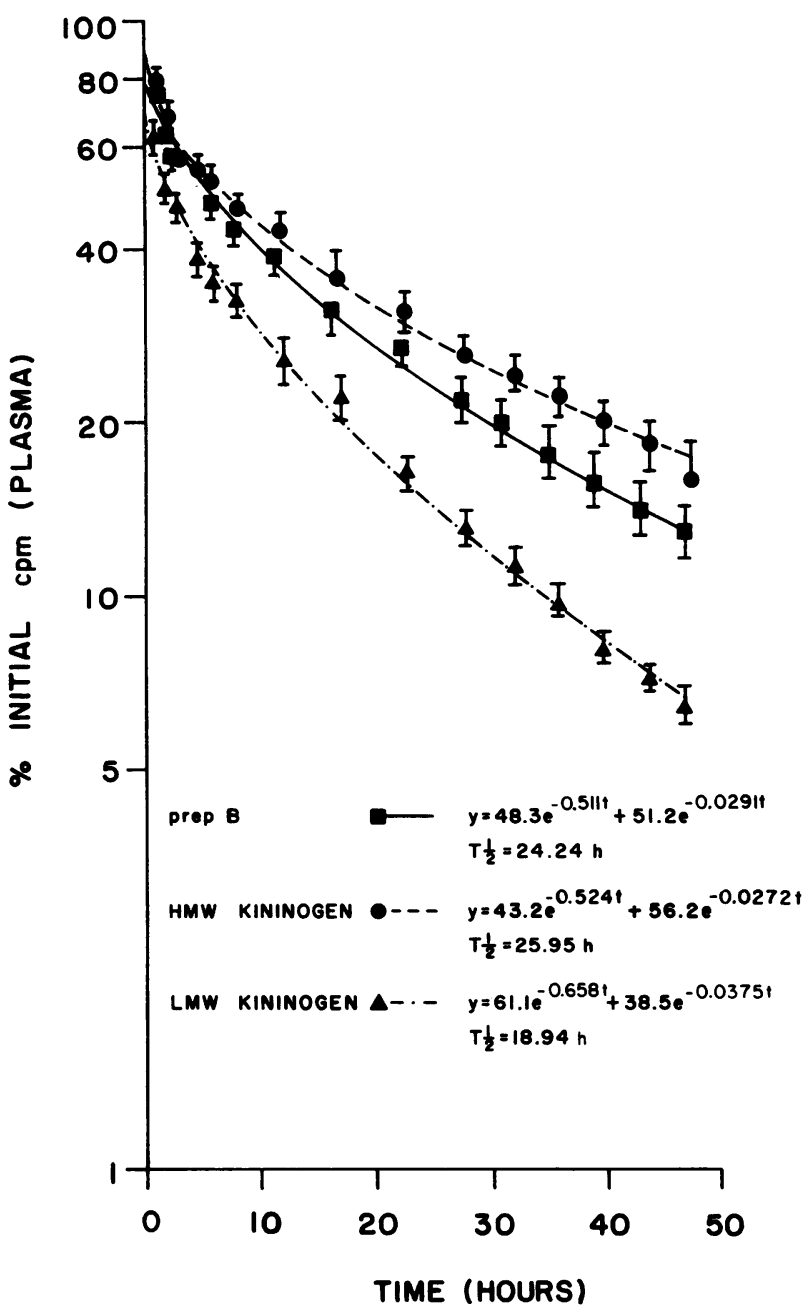

Figure 3 Turnover curves for human HMW, LMW, and mixed (prep B) kininogens. Radiolabeled proteins were administered intravenously to rhesus monkeys, and their disappearance from the plasma on a log scale was plotted against time. The points represent mean $\pm S E$ of 6,4 , and 6 studies for kininogens of high, low, and mixed molecular weight, respectively. The equations that best fit the data points and the plasma $t_{1 / 2}$ for each of the kininogens are depicted at the bottom.

The adequacy of the model for describing the system with double exponential equations was tested by two methods. First, the sum of the constants for the two exponentials $\left(C_{1}\right.$ and $\left.C_{2}\right)$ of each of the disappearance curves was measured. Theoretically, this value should approach $100 \%$ if there are no additional exponentials required for proper fit of the disappearance curves to the calculated equations. The results shown in Table II indicate that two exponentials are all that are required to provide a good fit for the turnover curves. The second method used to evaluate adequacy of fit was simple calculation of correlation 
TABLE I

Comparison of Kinetic Parameters for Disappearance of Radiolabeled HMW vs. LMW Kininogens from Plasma*

\begin{tabular}{lccccc}
\hline Kininogen & $\mathrm{t}_{1 / 2}$ & $\mathrm{Fc}$ & $\mathrm{Fi}, \mathrm{e}$ & $\mathrm{Fe}, \mathrm{i}$ & ev/iv \\
\hline HMW & $25.95 \pm 1.60$ & $1.12 \pm 0.08$ & $4.73 \pm 1.02$ & $7.20 \pm 1.02$ & $0.63 \pm 0.05$ \\
LMW & $18.94 \pm 1.93$ & $2.07 \pm 0.09$ & $7.40 \pm 2.64$ & $7.11 \pm 2.49$ & $1.05 \pm 0.07$ \\
$P$ & $<0.05$ & $<0.001$ & NS & NS & $<0.01$ \\
\hline
\end{tabular}

*Values given are mean $\pm \mathrm{SE}$.

coefficients for multiple regressions. Correlation $(r)$ values for the double exponentials were in excess of 0.9900 for all of the studies (Table III). Equally notable was the absence of any improvement in fit of the curves to triple exponential equations.

Measurement of turnover by following the disappearance of plasma radioactivity was compared with the disappearance of whole blood radioactivity and antibody-precipitated kininogen antigen radioactivity. Less than $10 \%$ of total radioactivity remained in the supernate after immunoprecipitation of kininogen. Turnover curves obtained by measuring whole blood and immunoprecipitated kininogen radioactivity were not significantly different from plasma studies, nor were they significantly different from each other. This was true for all forms of kininogen tested.

Because so-called HMW kininogen and LMW kininogen are each mixtures of kininogens of various molecular weights, their turnover curves were compared with those of the pure 80,000 and 225,000 molecular weight proteins, B3 $\alpha$ and B4 $\gamma$. As shown in Fig. 4, the turnover curves for $\mathrm{B} 3 \alpha$ and $\mathrm{B} 4 \gamma$ were not significantly different from their counterparts of lesser purity, which indicates that the heterogeneous composition of our HMW and LMW kininogen preparations did not alter the basic kinetic characteristics of their respective major components.

\section{TABLE II}

Sum of the Constants $\left(C_{1}+C_{2}\right)$ of the Two Exponentials Describing the Disappearance of Labeled Kininogen from Plasma

\begin{tabular}{cccc}
\hline Study & $\begin{array}{r}\text { Prep B } \\
\mathrm{C}_{1}+\mathrm{C}_{2}\end{array}$ & $\begin{array}{c}\text { HMW kininogen } \\
\mathrm{C}_{1}+\mathrm{C}_{2}\end{array}$ & $\begin{array}{c}\text { LMW kininogen } \\
\mathrm{C}_{1}+\mathrm{C}_{2}\end{array}$ \\
\hline & $\%$ & $\%$ & $\%$ \\
1 & 99.2 & 97.5 & 99.6 \\
2 & 98.5 & 97.6 & 99.8 \\
3 & 100.0 & 99.9 & 100.0 \\
4 & 99.9 & 100.0 & 99.9 \\
5 & 100.0 & 100.0 & \\
6 & 100.0 & 99.8 & \\
Mean \pm SD & $99.6 \pm 0.6$ & $99.1 \pm 1.2$ & $99.6 \pm 0.5$ \\
\hline
\end{tabular}

The data discussed have referred exclusively to turnover of human kininogens. Because of the phylogenetic similarity between monkeys and humans, and because of the identity in the measured biochemical and antigenic characteristics of their kininogens, we assumed that human kininogens would have similar turnover kinetics compared with monkey kininogens when studied in rhesus monkeys. The accuracy of this assumption was tested and our results are depicted in Fig. 5. The disappearance curves for radiolabeled monkey HMW and LMW kininogens fell within the $95 \%$ confidence limits of the curves for their corresponding human kininogens. While there was no difference in their plasma $t_{1 / 2}$, Fc of monkey LMW kininogen, $1.10 \pm 0.14 \mathrm{~d}^{-1}$ was significantly lower $(P<0.001)$ than that of human LMW kininogen, $2.07 \pm 0.09 \mathrm{~d}^{-1}$. There were no significant differences in $\mathrm{Fi}$, e or in $\mathrm{Fe}$, i to explain the lower catabolic rate, but the ev/iv for monkey LMW kininogen, $0.64 \pm 0.03$, was significantly smaller $(P$ $<0.01$ ) than that for human LMW kininogen, 1.052 \pm 0.068 .

\section{DISCUSSION}

We have characterized the normal turnover of kininogens by measuring their disappearance from the plasma

TABLE III

Correlation Coefficients ( $r$ ) Obtained by Fitting Disappearance of Labeled Kininogen to 2 vs. 3 Exponentials

\begin{tabular}{|c|c|c|c|c|c|c|}
\hline \multirow[b]{2}{*}{ Study } & \multicolumn{2}{|c|}{ Prep B } & \multicolumn{2}{|c|}{ HMW kininogen } & \multicolumn{2}{|c|}{ LMW kininogen } \\
\hline & $2 \exp ^{*}$ & $3 \exp$ & $2 \exp$ & $3 \exp$ & $2 \exp$ & $3 \exp$ \\
\hline & $r$ & $r$ & $r$ & $r$ & $r$ & $r$ \\
\hline 1 & 0.9961 & 0.9963 & 0.9506 & 0.9915 & 0.9963 & 0.9967 \\
\hline 2 & 0.9950 & 0.9951 & 0.9949 & 0.9953 & 0.9953 & 0.9962 \\
\hline 3 & 0.9999 & 0.9999 & 0.9997 & 0.9998 & 0.9998 & 0.9998 \\
\hline 4 & 0.9988 & 0.9998 & 0.9995 & 0.9996 & 0.9997 & 0.9998 \\
\hline 5 & 0.9996 & 0.9999 & 0.9989 & 0.9989 & & \\
\hline 6 & 0.9996 & 0.9998 & 0.9985 & 0.9985 & & \\
\hline
\end{tabular}

* Exponentials 


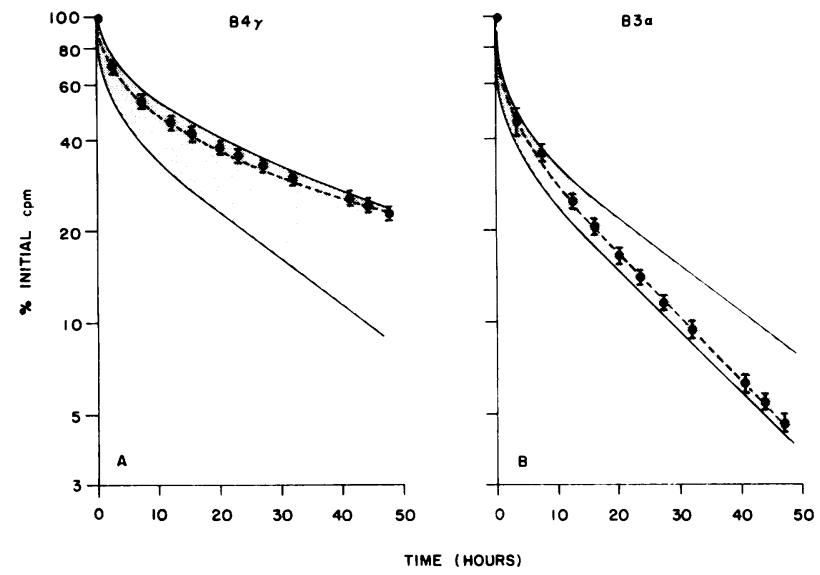

Figure 4 Comparison of disappearance curves for radiolabeled B4 $\gamma$ vs. HMW kininogen (A), and B3 $\alpha$ vs. LMW kininogen (B). The 95\% confidence limits for the turnover curves of HMW and LMW kininogens are represented by the shaded areas, and the circles (O) represent mean $\pm \mathrm{SE}$ of 4 studies each for B $4 \gamma$ and B3 $\alpha$.

of rhesus monkeys after bolus injection. The relatively rapid metabolic rate observed for kininogens indicated that kinetic analysis by the plasma slope method would be appropriate for the study of their turnover. Because terminal hydrolysis products of radioiodinated proteins are excreted at finite rates, methods of protein turnover analysis which involve measurement of urine radioactivity (24) can be inaccurate in the case of rapidly metabolized proteins (23). An inevitable lag period between catabolism and excretion exists for any protein; this lag period is short in the case of slowly metabolized proteins, but can be significant in rapidly metabolized proteins, and can result in a

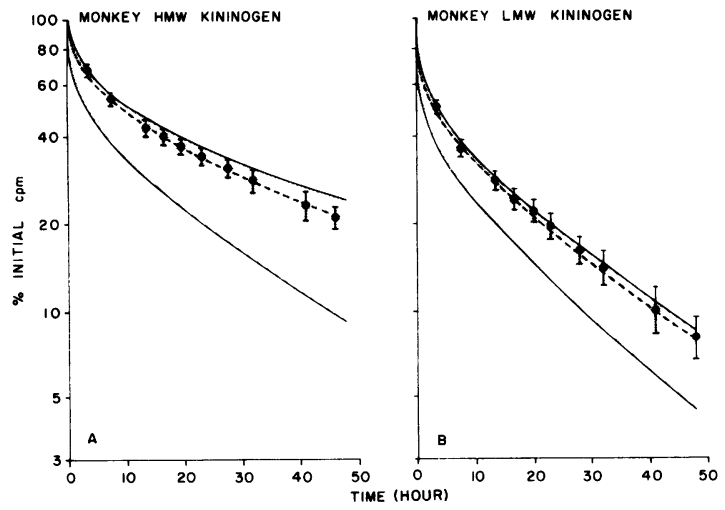

FigURE 5 Comparison of turnover curves for monkey HMW (A) and LMW (B) kininogens vs. their corresponding human proteins. The $95 \%$ confidence limits for the turnover curves of human HMW and LMW kininogens are represented by the shaded areas, and the circles (O) represent mean \pm SE of 4 studies each for monkey HMW and LMW kininogens. disequilibrium between catabolism and excretion. Such circumstances could create the erroneous appearance of a site of extravascular protein sequestration before catabolism. In addition to theoretical reasons for avoiding urine radioactivity measurements, the technical problem of obtaining accurate urine samples from monkeys without surgical intervention was virtually insurmountable.

Our results indicated that turnover of plasma kininogens conformed to double exponential equations. In measuring turnover by the plasma slope method, we assumed a simple system consisting of two pools: the intravascular pool into which radiolabeled kininogen was injected, and the single extravascular pool into which the injected kininogen diffused, or was catabolized. As we did not attempt complicated multicompartmental modeling analysis during our present study, the pools did not represent specific anatomic compartments, but were pools only in a kinetic sense. According to our assumption, kininogen could exit from the intravascular pool by only two processes: diffusion or catabolism. If our double exponential hypothesis were correct, the sum of the constants for the fraction of injected protein that diffuses $\left(C_{1}\right)$ and the fraction that is catabolized $\left(\mathrm{C}_{2}\right)$ should approximate $100 \%$. As our data indicated, the average values for $\mathrm{C}_{1}+\mathrm{C}_{2}$ were close to the predicted value, which suggests that there were no overlooked components to the equation describing kininogen turnover in plasma. We confirmed this observation by testing the fit of our data to triple exponentials, and observed no notable improvement in correlation coefficient. These results are in contradistinction to those observed in studies of fibrinogen turnover which, although said to conform to double exponential equations, indicate the presence of a small $(2-3 \%)$ third component in their turnover curves (23).

Analysis of our kininogen turnover curves was simplified, and accuracy was improved considerably with the SAAM computer program. Without the program, the constants for the double exponential equations would have had to be estimated by graphic means. By extrapolation of the terminal portion of the turnover curves to time 0 , the $y$-intercept $\left(C_{2}\right)$ and slope (-b) of the second exponential could be obtained, and by subtraction of the second exponential from the total curve, the constants $\left(C_{1}\right.$ and -a) for the first exponential could be calculated. With the SAAM program, we were able to perform iterations of the data to obtain constants for the curve that provided the best fit of our data to more than two exponentials without difficulty.

To follow the disappearance of radiolabeled kininogen from the intravascular pool, we compared measurements of whole blood, plasma, and antibody-precipi- 
tated kininogen radioactivities. There were no differences in turnover curves obtained with any of the three methods of analysis, although the last method was clearly the most specific. We were not able to measure the radioactivity of functionally active kininogen as opposed to kininogen antigen. In studies of fibrinogen turnover, this problem is not encountered because plasma samples can be clotted and the radioactivity of the fibrin contained within the clots counted. However, fibrinogen turnover curves obtained by measuring plasma radioactivity were nearly identical to those obtained by measuring radioactivity of clottable protein (25). While we cannot exclude the possibility that kininogen may continue to circulate in the intravascular pool as measurable antigen even after partial catabolism, it is unlikely, as a common pathway for diffusion and catabolism is suggested by the observation that the catabolic pattern for kininogen was superimposed by a similar kinetic for its diffusion.

The differences we observed between the kinetics of HMW and LMW kininogens cannot be explained simply on the basis of molecular size, because albumin, with a molecular weight less than that of LMW kininogen, has a $t_{1 / 2}$ nearly four times as long (20). The differences in Fc of the two kininogens were attributable primarily to differences in their ev/iv. It is tempting to speculate about the functions of the two kininogens in relation to their pool distribution, but we have little data with which to support such conjectures. However, the importance of HMW kininogen in the coagulation process has been well documented (26-29), although the specific in vivo functions of the various kininogens are otherwise unknown. In addition, Pierce and Guimarães (10) as well as Habal et al. (30) have corroborated earlier observations by Jacobsen and Kriz (31) that HMW kininogen is the preferred substrate for plasma kallikrein. These two observations are consistent with the predominant intravascular distribution of HMW kininogen, but do not shed further light on the relationship between distribution and function of the kininogens.

Turnover of rhesus monkey kininogens was similar to that of human kininogens when measured in monkeys. This was to be expected in view of the similarities between the kininogens of the two species. However, Regoeczi has shown that in rabbits, human fibrinogen disappeared at 1.45 times the rate of homologous fibrinogen before immunologic clearance mechanisms were activated (32). Similar studies in monkeys that were injected with human fibrinogen showed its clearance rate to be 1.3 times faster than that of the homologous fibrinogen, despite the absence of any detectable immune response (23). The difference in clearance rates was attributable to differences in diffusion rates as well as in ev/iv. We did not observe any significant differences in plasma $t_{1 / 2}$ between monkey and human kininogens, but the former had a slower catabolic rate than its human counterpart, and this difference was apparently related to the former's significantly greater distribution into the intravascular pool. The differences in ev/iv between the heterologous and homologous LMW kininogens may reflect differences in their functional characteristics in monkeys.

In their description of a patient with Flaujeac factor deficiency (16), a disease later shown by Wuepper et al. to be caused by deficiency in HMW kininogen (27), Lacombe et al. reported that the functional abnormality in coagulation observed in their patient could be corrected in vivo by the infusion of fresh frozen plasma. The factor(s) in fresh frozen plasma which corrected the functional deficiency had a $t_{1 / 2}$ of 6.5 days. Although this observation is apparently at variance with our $t_{1 / 2}$ for $\mathrm{HMW}$ kininogen of $25.95 \mathrm{~h}$, several important differences between Lacombe's study and ours must be considered: $(a)$ their study reports in vivo functional $t_{1 / 2}$, whereas our $t_{1 / 2}$ was derived from plasma disappearance curves; $(b)$ the exact substance of which $t_{1 / 2}$ was inferred in Lacombe's study is unclear, because they used fresh frozen plasma for infusion rather than purified HMW kininogen; (c) their $\mathrm{t}_{1 / 2}$ curve was drawn from three points in a single patient after one infusion of fresh frozen plasma; and $(d)$ a species difference in metabolic turnover of HMW kininogen cannot be excluded.

Because of their unique and potent physiologic actions, the kinins have been implicated in the pathophysiology of a number of severe clinical illnesses. Evidence of kinin system activation in these illnesses, however, has been inferential for the most part, because turnover of the proteins involved has not been evaluated. We have studied the syndrome of disseminated intravascular coagulation in Salmonella typhimurium-infected rhesus monkeys and, as in other illnesses with suspected kinin system participation, our evidence of kinin activation has been limited to the indirect observations of elevated kallikrein and diminished prekallikrein and kininogen (33). We are presently attempting to clarify the association between kinins and clinical illness by direct study of kininogen turnover in our infected monkeys, and by comparing with the normal studies presently discussed. In this fashion, we hope to be able to document the involvement of the kinin system in disseminated intravascular coagulation and to evaluate various potential therapeutic measures in relation to their effect on the kinin system. The technique for measuring kininogen turnover should also be applicable to the study of other illnesses in which the 
kinin system is thought to play an important pathophysiologic role.

\section{ACKNOWLEDGMENTS}

The authors wish to express their appreciation to Dr. J. David Gangemi, Mr. Edgar W. Larson, and Dr. William R. Beisel for their helpful criticism; Mrs. Phebe W. Summers for her editorial help; and Messrs. Glen A. Higbee and Dwayne D. Oland for their help with the computer analysis of our data. We gratefully acknowledge the technical assistance of Dr. Moacir de Sa Pereira; Messrs. Charles K. Ambrose and Steven A. Tobery; and Ms. Cathleen Schmidt.

\section{REFERENCES}

1. Erdös, E. G. 1970. Bradykinin, kallidin, and kallikrein. In Handbook of Experimental Pharmacology. Volume 25. Springer-Verlag New York, Inc., New York.

2. Eisen, V. 1970. Formation and function of kinins. Rheumatology. 3: 103-168.

3. Webster, M. E., and J. V. Pierce. 1963. The nature of the kallidins released from human plasma by kallikreins and other enzymes. Ann. N. Y. Acad. Sci. 104: 91-105.

4. Kaplan, A. P., and K. F. Austen. 1970. A pre-albumin activator of prekallikrein. J. Immunol. 105: 802-811.

5. Oates, J. A., and T. C. Butler. 1967. Pharmacologic and endocrine aspects of carcinoid syndrome. Adv. Pharmacol. 5: 109-128.

6. Donaldson, V. H. 1968. Mechanism of activation of C'1 esterase in hereditary angioneurotic edema plasma in vitro: the role of Hageman factor, a clot-promoting agent. J. Exp. Med. 127: 411-429.

7. Wong, P. Y., R. C. Talamo, B. M. Babior, G. G. Raymond, and R. W. Colman. 1974. Kallikrein-kinin system in postgastrectomy dumping syndrome. Ann. Intern. Med. 80: $577-581$.

8. Mason, J. W., U. Kleeberg, P. Dolan, and R. W. Colman. 1970. Plasma kallikrein and Hageman factor in Gramnegative bacteremia. Ann. Intern. Med. 73: 545-551.

9. Minna, J. D., S. J. Robboy, and R. W. Colman. 1974. Disseminated Intravascular Coagulation in Man. Charles C. Thomas, Publisher, Springfield, Ill., 70-76.

10. Pierce, J. V., and J. A. Guimarães. 1976. Further chatacterization of highly purified human plasma kininogens. In Chemistry and Biology of the KallikreinKinin System in Health and Disease. Fogarty International Proceedings No. 27. J. J. Pisano and K. F. Austen, editors. U. S. Government Printing Office, Washington, D. C. $121-127$.

11. Deutsch, D. G., and E. T. Mertz. 1970. Plasminogen: purification from human plasma by affinity chromatography. Science (Wash. D. C.). 170: 1095-1096.

12. March, S. C., I. Parikh, and P. Cuatrecasas. 1974. A simplified method for cyanogen bromide activation of agarose for affinity chromatography. Anal. Biochem. 60: 149-152.

13. Pierce, J. V., and M. E. Webster. 1966. The purification and some properties of two different kallidinogens. In Hypotensive Peptides. E. G. Erdös, N. Back, and F. Sicuteri, editors. Springer-Verlag, New York, Inc., New York. 130-138.

14. Prado, E. S., J. L. Prado, and C. M. W. Brandi. 1962. Further purification and some properties of horse urinary kallikrein. Arch. Int. Pharmacodyn. Ther. 137: 358-374.

15. Webster, M. E., and E. S. Prado. 1970. Glandular kallikreins from horse and human urine and from hog pancreas. Methods Enzymol. XXIX: 681-699.
16. Lacombe, M-J., B. Varet, and J-P. Levy. 1975. A hitherto undescribed plasma factor acting at the contact phase of blood coagulation (Flaujeac factor): case report and coagulation studies. Blood. 46: 761-768.

17. Gruber, J., and G. G. Wright. 1967. Iodine-131 labeling of purified microbial antigens by microdiffusion. Proc. Soc. Exp. Biol. Med. 126: 282-284.

18. Reeve, E. B., and H. R. Bailey. 1962. Mathematical models describing the distribution of $\mathrm{I}^{131}$-albumin in man. J. Lab. Clin. Med. 60: 923-943.

19. Berman, M., and M. F. Weiss. 1967. SAAM Manual. U. S. Government Printing Office, Washington, D. C. U. S. Public Health Service Publication No. 1703.

20. Dixon, W. J., and F. J. Massey, Jr. 1969. Introduction to Statistical Analysis. 3rd edition. McGraw-Hill Book Company, New York, 210-215.

21. Regoeczi, E. 1974. Fibrinogen. In Structure and Function of Plasma Proteins. A. C. Allison, editor. Plenum Publishing Corporation, New York. 1: 133-168.

22. Atencio, A. C., H. R. Bailey, and E. B. Reeve. 1965. Studies on the metabolism and distribution of fibrinogen in young and older rabbits. I. Methods and models. J. Lab. Clin. Med. 66: 1-19.

23. Atencio, A. C., and E. B. Reeve. 1965. Studies on the metabolism and distribution of fibrinogen in young and older rabbits. II. Results. J. Lab. Clin. Med. 66: 20-33.

24. McFarlane, A. S. 1957. The behavior of I $^{131}$-labeled plasma proteins in vivo. Ann. N. Y. Acad. Sci. 70: 19-25.

25. Regoeczi, E. 1967. Measuring the coagulability of fibrinogen in plasma by isotopic means. Method and principles of its use for in vivo studies. Thromb. Diath. Haemorrh. 18: 276-285.

26. Colman, R. W., A. Bagdasarian, R. C. Talamo, C. F. Scott, M. Seavey, J. A. Guimarães, J. V. Pierce, and A. P. Kaplan. 1975. Williams trait. Human kininogen deficiency with diminished levels of plasminogen proactivator and prekallikrein associated with abnormalities of the Hageman factor-dependent pathways. J. Clin. Invest. 56: 1650-1662.

27. Wuepper, K. D., D. R. Miller, and M. J. Lacombe. 1975. Flaujeac trait. Deficiency of human plasma kininogen. J. Clin. Invest. 56: 1663-1672.

28. Donaldson, V. H., H. I. Glueck, M. A. Miller, H. Z. Movat, and F. Habal. 1976. Kininogen deficiency in Fitzgerald trait: role of high molecular weight kininogen in clotting and fibrinolysis. J. Lab. Clin. Med. 87: 327-337.

29. Matheson, R. T., D. R. Miller, M-J. Lacombe, Y. N. Han, S. Iwanaga, H. Kato, and K. D. Wuepper. 1976. Flaujeac factor deficiency. Reconstitution with highly purified bovine high molecular weight-kininogen and delineation of a new permeability-enhancing peptide released by plasma kallikrein from bovine high molecular weight-kininogen. J. Clin. Invest. 58: 1395-1406.

30. Habal, F. M., H. Z. Movat, and C. E. Burrowes. 1974. Isolation of two functionally different kininogens from human plasma-separation from proteinase inhibitors and interaction with plasma kallikrein. Biochem. Pharmacol. 23: 2291-2303.

31. Jacobsen, S., and M. Kriz. 1967. Some data on two purified kininogens from human plasma. Br.J.Pharmacol. 29: 25-36.

32. Regoeczi, E. 1970. Fibrinogen catabolism: kinetics of catabolism following sudden elevation of the pool with exogenous fibrinogen. Clin. Sci. (Oxf.). 38: 111-121.

33. Wing, D. A., T. Yamada, H. B. Hawley, and G. W. Pettit. 1978. Model for disseminated intravascular coagulation: bacterial sepsis in rhesus monkeys. J. Lab. Clin. Med. 92: 239-251. 